\title{
The nucleotide and partial amino acid sequences of rat fetuin Identity with the natural tyrosine kinase inhibitor of the rat insulin receptor
}

\author{
Günther RAUTH ${ }^{1}$, Oliver PÖSCHKE ${ }^{1}$, Edwin FINK ${ }^{1}$, Manfred EULITZ ${ }^{3}$, Stefanie TIPPMER ${ }^{4}$, Monika KELLERER ${ }^{4}$, \\ Hans-Ulich HÄRING ${ }^{4}$, Peter NAWRATIL ${ }^{1}$, Martina HAASEMANN ${ }^{1}$, Willi JAHNEN-DECHENT ${ }^{1}$ and Werner MÜLLER-ESTERL ${ }^{1}$ \\ 1 Institut für Physiologische Chemie und Pathobiochemie, Universität Mainz, Federal Republic of Germany \\ 2 Institut für Klinische Chemie und Klinische Biochemie, Universität München, Federal Republic of Germany \\ ${ }^{3}$ Institut für Klinische Molekularbiologie, Gesellschaft für Strahlen- und Umweltforschung, München, Federal Republic of Germany \\ ${ }^{4}$ Institut für Diabetesforschung und III. Medizinische Abteilung, Krankenhaus Schwabing, München, Federal Republic of Germany
}

(Received September 26, 1991) - EJB 911283

Fetuins are among the major plasma proteins, yet their biological role has remained elusive. Here we report the molecular cloning of rat fetuin and the sequence analysis of a full-length clone, RF619 of $1456 \mathrm{bp}$ with an open reading frame of $1056 \mathrm{bp}$ encoding 352 amino acid residues. The coding part of RF619 was identical with the cDNA sequence of the natural inhibitor of the insulin receptor tyrosine kinase from rat (pp63) except for four substitutions and a single base insertion causing divergence of the predicted protein sequences. Partial amino acid sequences of rat plasma fetuin were in agreement with the predictions based on the RF619 cDNA. Purified rat fetuin inhibited the insulin receptor tyrosine kinase in vitro. Therefore, we conclude that RF619 and pp63 cDNA encode the same protein, i.e. authentic rat fetuin which is a functional tyrosine kinase inhibitor.

Fetuins are among the most abundant proteins of fetal plasma. The bovine protein, first identified and named fetuin by Pedersen (1944), is present in fetal plasma at concentrations reaching $5 \mathrm{~g} / \mathrm{l}$. The corresponding human protein, $\alpha_{2}-\mathrm{HS}$ glycoprotein (Schultze et al., 1962) was isolated from adult human plasma (Schmid and Bürgi, 1961) and later recognized as the human homologue of bovine fetuin (Christie et al., 1987). Prefetuins are secretory proteins of approximately 360 amino acid residues. They are post-translationally modified by proteolytic cleavage into a two-chain form (Kellermann et al., 1989), by $N$ - and $O$-glycosylation (Edge et al., 1987; Yet et al., 1988) and/or by sulfation (Hortin et al., 1986). Structural and evolutionary studies revealed that fetuins possess a tripartite structure, i.e. two $\mathrm{N}$-terminally located domains (D1, D2) of cystatin-like structure, followed by a unique $\mathrm{COOH}$-terminal domain (D3) unrelated to other mammalian proteins (Elzanowski et al., 1988).

Although much is known about the structure and biosynthesis of the fetuins, the central question of their biological role(s) has remained elusive. Bovine fetuin is widely used as an additive to cell culture media because it promotes cell growth (Puck et al., 1968). Accumulation of $\alpha_{2}$-HS glycoprotein in the non-collagenous bone matrix has suggested a role of the protein in enchondral ossification (Triffitt et al.,

Correspondence to W. Müller-Esterl, Institute for Physiological Chemistry and Pathobiochemistry, The University of Mainz, Duesbergweg 6, W-6500 Mainz 1, Federal Republic of Germany

Abbreviation. RF, rat fetuin clones.

Enzyme. Trypsin (EC 3.4.21.4).

Note. The novel nucleotide sequence data published here have been submitted to the EMBL sequence data bank and are available under accession number X63446.
1976; Yang et al., 1991). Furthermore, functional roles for mammalian fetuins have been proposed in the regulation of lipogenesis (Cayatte et al., 1990), endocytosis (Lewis and André, 1980), opsonization (van Oss et al., 1974) and inflammation (Daveau et al., 1990). Each of these functions, however, applies to a species-specific fetuin, but none represents a universal role for the fetuins.

Recently we demonstrated an unexpected sequence similarity between human $\alpha_{2}$-HS glycoprotein, bovine fetuin, and the natural inhibitor of the rat insulin receptor tyrosine kinase, pp63 (Haasemann et al., 1991). Overall sequence identity was $56-60 \%$ (percentage residues in identical positions of the proteins), indicating that pp63 might represent a structurally related, but functionally distinct, protein of the rat, or the rat homologue of human and bovine fetuins (Haasemann et al., 1991; Falquerho et al., 1991; Brown et al., 1991).

Here we have set out to further define the structural and functional relationship between fetuins and pp63. Screening of a rat liver cDNA library with a cDNA probe derived from a human $\alpha_{2}$-HS glycoprotein cDNA resulted in the isolation of a full-length clone (RF619) encoding rat fetuin. The protein sequence predicted from the RF619 cDNA is similar to the protein sequence derived from clone pp63 except for the Cterminal region where the two sequences diverge. The results from direct amino acid sequence analyses of fetuin isolated from rat plasma were in agreement with the predictions from the RF619, but not from the pp63 cDNA. In vitro experiments demonstrated that purified rat fetuin significantly and reproducibly inhibits the tyrosine kinase activity associated with partially purified human insulin receptor. Therefore, we conclude that clones RF619 and pp63 encode the same protein, i.e. authentic rat fetuin, a tyrosine kinase inhibitor. 


\section{EXPERIMENTAL PROCEDURES}

\section{Rat fetuin cDNA clones}

A $\lambda$ ZAP II cDNA library prepared from rat liver mRNA (Stratagene) was plated out at a density of $2 \times 10^{4}$ plaqueforming units $/ 90-\mathrm{mm}$ dish. Out of 400000 independent recombinants, five clones (RF619, RF1b1, RF6b1, RF6b2, RF15b2) were selected which strongly hybridized to a 1600 bp cDNA encoding human $\alpha_{2}$-HS glycoprotein (R. Vogel and W. Müller-Esterl, unpublished results). This probe was ${ }^{32} \mathrm{P}$ labeled, typically to a specific activity of $5 \times 10^{8} \mathrm{dpm} / \mu \mathrm{g}$, using random primers (Feinberg and Vogelstein, 1983). The nitrocellulose filters (Schleicher and Schuell) were washed in $2 \times \mathrm{NaCl} / \mathrm{Cit}(\mathrm{NaCl} / \mathrm{Cit}$ : $0.15 \mathrm{M}$ sodium citrate, $0.15 \mathrm{M}$ sodium chloride, $\mathrm{pH} 7.0$ ) and $0.1 \%$ SDS for $1 \mathrm{~h}$ at $55^{\circ} \mathrm{C}$ and autoradiographed.

\section{Hybridization techniques}

RNA from different rat organs were isolated according to the guanidine-isothiocyanate/CsCl method (Davis et al., 1986). Rat genomic DNA for Southern-blot analysis was purchased from Clontech. Northern and Southern hybridizations were carried out as described (Sambrook et al., 1989). In both hybridization experiments, a poly(vinylidene difluoride) membrane (Millipore) was used. The probe was derived from a 1300-bp EcoRI fragment of clone RF619, and was ${ }^{32} \mathrm{P}$ labeled using the random-primer technique. Final washes were in $0.1 \times \mathrm{NaCl} / \mathrm{Cit}$ containing $0.1 \% \mathrm{SDS}$ for $1 \mathrm{~h}$ at $65^{\circ} \mathrm{C}$ for Northern blots, and in $\mathrm{NaCl} / \mathrm{Cit}$ containing $0.1 \%$ SDS for $30 \mathrm{~min}$ at $65^{\circ} \mathrm{C}$ for Southern blots.

\section{Sequencing strategy}

Plasmid and single-stranded DNA of the five $\lambda$ ZAP II clones containing rat fetuin sequences were isolated by rescue excision according to the manufacturer's instructions (Stratagene). The complete nucleotide sequence of clone RF619 and the partial nucleotide sequences of clones RF1b1, RF6b1, RF6b2 and RF15b2 were established by the chaintermination method (Sanger et al., 1977) using a T7 sequencing kit (Pharmacia).

\section{Rat fetuin isolation}

The purification procedure for rat fetuin is based on the isolation scheme for plasma acid-stable trypsin inhibitors of the plasma (Albrecht et al., 1983). Heparinized rat plasma (194 ml) was mixed with $1: 10$ vol. $12 \mathrm{M}$ perchloric acid. The mixture was incubated for $30 \mathrm{~min}$ at $4^{\circ} \mathrm{C}$ then centrifuged $(20 \mathrm{~min} 4200 \times g)$. The supernatant was removed and adjusted to $\mathrm{pH} 7.8(2 \mathrm{M} \mathrm{KOH})$. After $14 \mathrm{~h}$ at $4^{\circ} \mathrm{C}$, the resultant precipitate was removed by centrifugation $(4200 \times \mathrm{g}, 20 \mathrm{~min})$. To the supernatant $(165 \mathrm{ml}), 5 \mathrm{ml}$ trypsin-Sepharose prepared from $1.5 \mathrm{~g} \mathrm{BrCN}$-Sepharose (Pharmacia) and $30 \mathrm{mg} N^{\alpha}$-tosylphenylalaninechloromethane-treated bovine trypsin (Sigma) was added and the suspension was rotated end-over-end $\left(1 \mathrm{~h}, 4^{\circ} \mathrm{C}\right)$. The gel was transferred into a column and unbound protein was washed out with $25 \mathrm{ml}$ equilibration buffer $(0.05 \mathrm{M}$ Tris, $0.1 \mathrm{M} \mathrm{KCl}, \mathrm{pH} 8.0$ ). Bound proteins were eluted with $1 \mathrm{M}$ $\mathrm{KCl}, \mathrm{pH} 2.2(\mathrm{HCl})$, and fractions of $0.5 \mathrm{ml}$ were collected. Trypsin inhibitor activity was determined using $N^{\alpha}$-benzoyl-Larginine-4-nitroanilide as the substrate. Fractions containing trypsin-inhibiting activity were pooled and subjected to reversed-phase HPLC on a Hypersil WP-300 butyl column
$(4.6 \mathrm{~mm} \times 250 \mathrm{~mm})$. The mobile phase was composed of solvent $\mathrm{A}[0.1 \%$ (by vol.) trifluoroacetic acid in water] and solvent $\mathrm{B}[0.1 \%$ (by vol.) trifluoroacetic acid in acetonitrile]. The gradient consisted of five linear segments ranging over 22$40 \% \mathrm{~B}$ in $\mathrm{A}$. The effluent was continuously monitored at $216 \mathrm{~nm}$. The solvent flow was $1 \mathrm{ml} / \mathrm{min}$ and fractions of $0.5 \mathrm{ml}$ were collected.

\section{Amino acid sequence analysis}

Isolated proteins were reduced, alkylated with iodoacetic acid or 4-vinylpyridine and desalted on a PD-10 column (Pharmacia) with water/formic acid/2-propanol $(5: 4: 1$, by vol.). For digestion with endoproteinase Lys-C (Boehringer Mannheim), polypeptides were incubated with $1-2 \%$ (by mass) enzyme in $25 \mathrm{mM}$ Tris $/ \mathrm{HCl}$ and $1 \mathrm{mM}$ EDTA, $\mathrm{pH} 8.5$, for $19 \mathrm{~h}$ at $37^{\circ} \mathrm{C}$. Further separation of the modified peptides was accomplished by reversed-phase HPLC. Amino acid sequences were determined with a gas-phase sequencer (Applied Biosystems, Model 477A) connected to an on-line HPLC 120A system for identification of the phenylthiohydantoin derivatives. Typically, $50-200 \mathrm{pmol}$ peptide/run was applied. The repetitive yields of representative runs ranged over 89.1 $94.8 \%$.

\section{Receptor preparation}

Human placenta tissue $(9-10 \mathrm{~g})$ was homogenized in $25 \mathrm{mM}$ Hepes, pH 7.5 (homogenization buffer), including $2.5 \mathrm{mM}$ phenylmethylsulfonylfluoride, $1200 \mathrm{U} / 1$ aprotinin, $10 \mathrm{mM}$ benzamidine and $7500 \mathrm{U} / \mathrm{l}$ bacitracin using an Ultraturrax blender. The homogenate was centrifuged $\left(150000 \times g, 20 \mathrm{~min}, 4^{\circ} \mathrm{C}\right)$. The supernatant was discarded and the pelleted material was treated $\left(30 \mathrm{~min}, 4^{\circ} \mathrm{C}\right)$ with homogenization buffer containing $1 \%$ Triton $X-100$. Following centrifugation $(200000 \times \mathrm{g}, 50 \mathrm{~min})$ to remove insoluble material, the supernatant was diluted fourfold with homogenization buffer including $0.05 \%$ Triton $X-100$ (dilution buffer). The solubilized membranes were applied to a column of wheat-germ agglutinin agarose $(2 \mathrm{ml})$ followed by extensive washing with dilution buffer. The bound material was eluted with $0.3 \mathrm{M} \mathrm{N}$-acetylglucosamine dissolved in the same buffer. The protein concentration of the collected samples was determined by a colorimetric assay (Bio-Rad). Fractions with the highest protein content were pooled and stored under liquid nitrogen.

\section{Substrate phosphorylation}

Partially purified insulin receptor protein $(1.5-2 \mu \mathrm{g})$ was treated with insulin $(1 \mu \mathrm{M})$ in the absence or presence of rat fetuin $(1.8-1100 \mathrm{pM})$, human $\alpha_{2}$-HS glycoprotein, bovine fetuin, human L-kininogen or human His-rich glycoprotein (all at $50 \mu \mathrm{g} / \mathrm{ml} ; 0.74-1.1 \mathrm{nM}$ ) for $30 \mathrm{~min}$ at $22^{\circ} \mathrm{C}$. This was followed by incubation $\left(10 \mathrm{~min} 22^{\circ} \mathrm{C}\right)$ with 0.5 to $5.0 \mu \mathrm{M}$ ATP supplemented with trace amounts of $\left[\gamma^{32} \mathrm{P}\right] \mathrm{ATP}(5 \mu \mathrm{Ci}$; specific activity, $3000 \mathrm{Ci} / \mathrm{mmol}$; NEN) in a final volume of $30 \mu \mathrm{l} 25 \mathrm{mM}$ Hepes, $\mathrm{pH} 7.5$, containing $0.05 \%$ Triton $\mathrm{X}-100$, $12 \mathrm{mM} \mathrm{MgCl}, 12 \mathrm{mM} \mathrm{MnCl}$ and $1 \mathrm{mM}$ sodium vanadate. Substrate phosphorylation was initiated by adding $1 \mathrm{mM}$ poly(Glu,Tyr) (4:1, sodium salt). The reaction was stopped after 20 min by transferring the mixtures to Whatman $3 \mathrm{MM}$ paper squares soaked with $20 \mathrm{mM}$ sodium pyrophosphate in $10 \%$ trichloroacetic acid. The filters were washed seven times in the same fixation agent and bound radioactivity was 
quantified by liquid scintillation counting. The basal activity (395221 $\mathrm{cpm} \cdot \mathrm{h}^{-1} \cdot \mathrm{\mu g}^{-1}$ ) of the receptor tyrosine kinase was increased $3.5 \pm 0.3$-fold by insulin; this stimulated state was arbitrarily ascribed $100 \%$ activity.

\section{Receptor binding studies}

Samples, each containing $2.5 \mu \mathrm{g}$ partially purified receptor protein, were incubated with $50 \mathrm{mM}$ Tris buffer, $\mathrm{pH} 7.5$, containing $10 \mathrm{mM} \mathrm{MgSO} 4,1 \%$ bovine serum albumin, 20000 cpm ${ }^{125} \mathrm{I}$-insulin (specific activity $2200 \mathrm{Ci} / \mathrm{mmol}$, NEN) and decreasing concentrations $(0.1-1000 \mathrm{nM})$ of unlabeled insulin, in the presence or absence of rat fetuin $(24 \mu \mathrm{g} / \mathrm{ml} ; 0.5 \mathrm{nM})$ for $45 \mathrm{~min}$ at $22^{\circ} \mathrm{C}$ (final volume, $125 \mu \mathrm{l}$ ). Separation of free and receptor-bound insulin was accomplished by dextrancoated charcoal. The amount of ${ }^{125} \mathrm{I}$-insulin bound to the receptor was quantified in a $\gamma$ counter.

\section{Receptor autophosphorylation}

Partially purified receptor protein $(3-3.5 \mu \mathrm{g})$ was incubated $\left(22^{\circ} \mathrm{C}, 30 \mathrm{~min}\right)$ with insulin $(1 \mu \mathrm{M})$ in the absence or presence of $30 \mu \mathrm{g} / \mathrm{ml}(0.67 \mathrm{nM})$ rat fetuin or $50 \mu \mathrm{g} / \mathrm{ml}$ $(0.74 \mathrm{nM})$ human L-kininogen. This was followed by incubation at $22^{\circ} \mathrm{C}$ with $5 \mu \mathrm{M}$ ATP supplemented with trace amounts of $\left[\gamma^{32}\right.$ P]ATP $(10 \mu \mathrm{Ci})$ in $25 \mathrm{mM}$ Hepes, $\mathrm{pH} 7.5$, containing $0.05 \%$ Triton $\mathrm{X}-100,10 \mathrm{mM} \mathrm{MnCl}$ and $1 \mathrm{mM}$ sodium vanadate. The incubation was terminated by the addition of SDS sample buffer, containing $100 \mathrm{mM}$ dithiothreitol, and subsequent boiling for $25 \mathrm{~min}$. The phosphoproteins were separated by SDS/PAGE in a 7.5\% polyacrylamide gel (Laemmli, 1970) and identified by autoradiography. ${ }^{32} \mathrm{P}-$ labeled bands were cut from the gel and Cerenkov radiation was measured.

\section{RESULTS}

\section{Molecular cloning of rat fetuin cDNA}

A cDNA probe was generated by random priming using a human $\alpha_{2}$-HS glycoprotein cDNA as the template. We screened a cDNA library constructed from rat liver mRNA in phage $\lambda$ ZAP II and identified multiple clones (approximately $0.3 \%$ of 400000 independent recombinants) which specifically hybridized to the probe. Five of them (designated RF) were plaque-purified, and their inserted cDNA were characterized by sequence analysis using universal primers. Clone RF619 comprised a full-length cDNA of approximately $1500 \mathrm{bp}$, whereas the other clones (RF1b1, RF6b1, RF6b2, RF15b2) contained incomplete cDNA covering $800-1400$ bp of the rat fetuin CDNA (not shown). Sequence analysis by the specific primer-directed strategy (Strauss et al., 1986) revealed that clone RF619 contains $1456 \mathrm{bp}$, including $31 \mathrm{bp}$ of the untranslated $5^{\prime}$ end, 1056 bp encoding the entire rat prefetuin molecule, and $369 \mathrm{bp}$ of the $3^{\prime}$ untranslated region, including the polyadenylation signal of AAT AAA, and a poly(A) tail of eight residues (Fig. 1). The open reading frame of clone RF619 translates into a protein of 352 amino acid residues (37939 Da) containing 14 cysteine residues, a potential signal peptide of 18 residues (including two cysteine residues), three potential $\mathrm{N}$-glycosylation sites of the general structure AsnXaa-Thr/Ser and two dibasic cleavage sites of Arg-Lys/Arg.

In a Northern-blot analysis, we used a randomly primed probe derived from the RF619 template to detect hybridizing message in total RNA from various rat tissues. These exper-


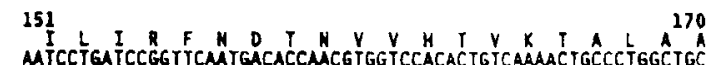

MIICCTGATCCGGTYCMATGACACCMACGTGGTCCACACTGTCAAACTOCCCCTGGĆ IGĆ



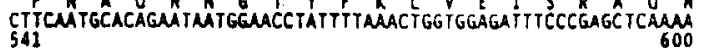

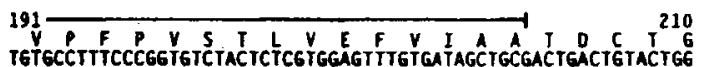

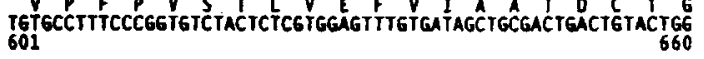
${ }^{211}{ }_{0}$ E $T$ P P A K C


$231^{-1}$

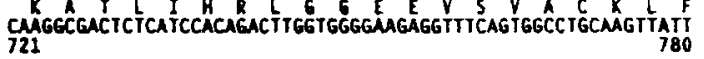

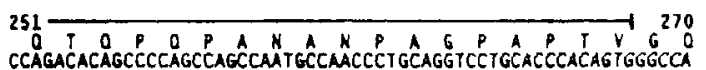
7CAGACACAGCCCCAGCCAGCCMATGCCAACCCTGCAGGTCCTGCACCCACAGTGGGCCA

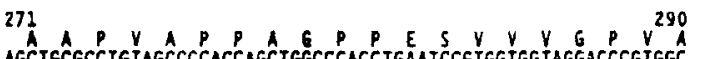

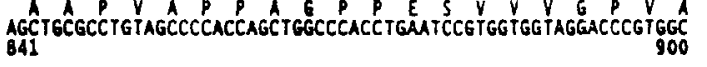
$291, p$ AGGTCCTCTAGGACTICCAGACCACCEUCCCACCATGACCTACGGCATGCCTICICTCC 311 IGGGGCTTCTGTGGAGTCGGCCTCAGGAGAGTTCITCACTCACCTAAGG TGGCCAGCC

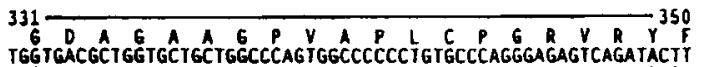

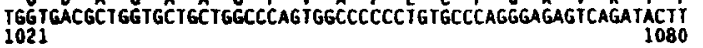
$-1352$

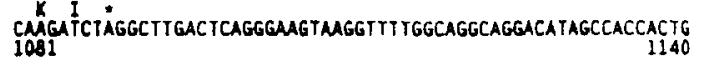
MagTAGAgGGCITGICCACTGACCMGCMGTACCACATCATAGCTTGMIITAGGICIC
1200 IICATICCCCAGAGMUUGGGGCAGAGAGGTGATGGTIMAMTITGTIGAMAGCCAGCAGC
1201
1260 AGCMACACTAGCACTIGTGGgGTGACAGACIACTGICATTIGTTICTITGCCTTCICACI
1261 GACCICATACMAGCAGTTGCMGCGCGACTGTGAAAGG TGCTCTCACCMMCTTCMTC IACCCATMATMMAG TACCCGAGGAGCTITCTTAUACMGMGGTICTGAGCCGAGTE
I381

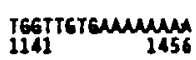

Fig. 1. The cDNA sequence for rat fetuin and its deduced amino acid sequence derived from clone RF619. The numbers below (above) the lines refer to the nucleotide (amino acid) sequence. The stop codon is marked by an asterisk, and the polyadenylation signal, AAT AAA, is underlined. The bold line above the protein sequence identifies the signal peptide (von Heijne, 1986). Portions of the protein sequence were verified by amino acid sequence analysis (upper thick lines). 
iments indicated that the major site of biosynthesis of rat fetuin is the liver; a single species of mRNA of approximately 1600 bp was found (not shown). RNA extracted from brain, lung, kidney, spleen and uterus failed to give a positive signal, even after prolonged exposure. Southern-blot analysis of rat genomic DNA digested by the restriction enzymes EcoRI, HindIII or BamHI in each case revealed a single fragment hybridizing to the RF619 probe (not shown). This indicates the existence of a single copy gene for fetuin present in the rat genome.

\section{Sequence comparison of RF619 and pp63 cDNA}

Comparison of the cDNA sequences of clones RF619 and pp63 (Auberger et al., 1989) revealed that the two sequences are almost identical in their core parts but diverge in their flanking regions. The $5^{\prime}$ end of the pp63 cDNA, containing a putative initiator codon AUG, is not present in clone RF619, whereas a second AUG codon, located $51 \mathrm{bp}$ downstream of the putative pp63 initiator codon is found in both cDNA. The latter, but not the former, site is preceded by the sequence GCC, a prototypic sequence motif flanking the translationinitiation sites in eukaryotic mRNA (Kozak, 1989), and coincides with the known translation-initiation sites of mammalian fetuins (Haasemann et al., 1991). Moreover, the $5^{\prime}$ untranslated regions of the RF15b2 cDNA (not shown), extending the RF619 sequence by $9 \mathrm{bp}$, diverges from the pp63 cDNA, but is in complete agreement with the corresponding genomic sequence of pp63 (Falquerho et al., 1991), suggesting that the $5^{\prime}$ region of the pp63 cDNA is a cloning artifact. No differences between the two cDNA exist at the $3^{\prime}$ end, except that RF619 extends the pp63 cDNA by 32 bp including a poly(A) tail of eight residues.

The sequences of the coding parts of RF619 and pp63 are congruent except for four substitutions at position $167(\mathrm{G} \rightarrow \mathrm{C}$; Asp $\rightarrow$ His), position $257(\mathrm{G} \rightarrow \mathrm{C}$; Glu $\rightarrow$ Gln) and positions 842/ 843 (GC $\rightarrow$ CG; Ala $\rightarrow$ Arg; RF619 numbering). Furthermore, an extra $G$ residue was assigned to position 1041 of the RF619 sequence which is not present in the pp63 cDNA (Fig. 2). The presence of an extra $G$ residue was confirmed on both strands of the RF619 cDNA and further established by the partial sequence analysis of clone RF6b1 (not shown). Insertion of a single G residue results in a frame shift causing divergence of the C-terminal portions of the protein sequences predicted from the RF619 and pp63 cDNA (Fig. 3). To resolve this discrepancy, partial amino acid sequences of rat fetuin were established.

\section{Isolation and characterization of rat fetuin}

Bovine fetuin is an effective inhibitor of bovine trypsin (Rohrlich and Rifkin, 1981). In a strategy exploiting the potential trypsin-binding properties of the rat protein, we isolated fetuin from rat plasma applying affinity chromatography on trypsin-Sepharose-4B. The purified protein had an apparent molecular mass of approximately $45 \mathrm{kDa}$, indicating that it might have undergone proteolytic cleavage (note that the apparent molecular masses of mammalian fetuins are approximately of $50-60 \mathrm{kDa}$ ). Reductive cleavage of the disulfide bonds and separation of the released chains of rat fetuin led to the identification of two major fragments (RFI-3.1 and RFI-1), indicating that the rat fetuin had been isolated in a two-chain form. Edman degradation was employed to establish the (partial) amino acid sequences of the isolated fragments.

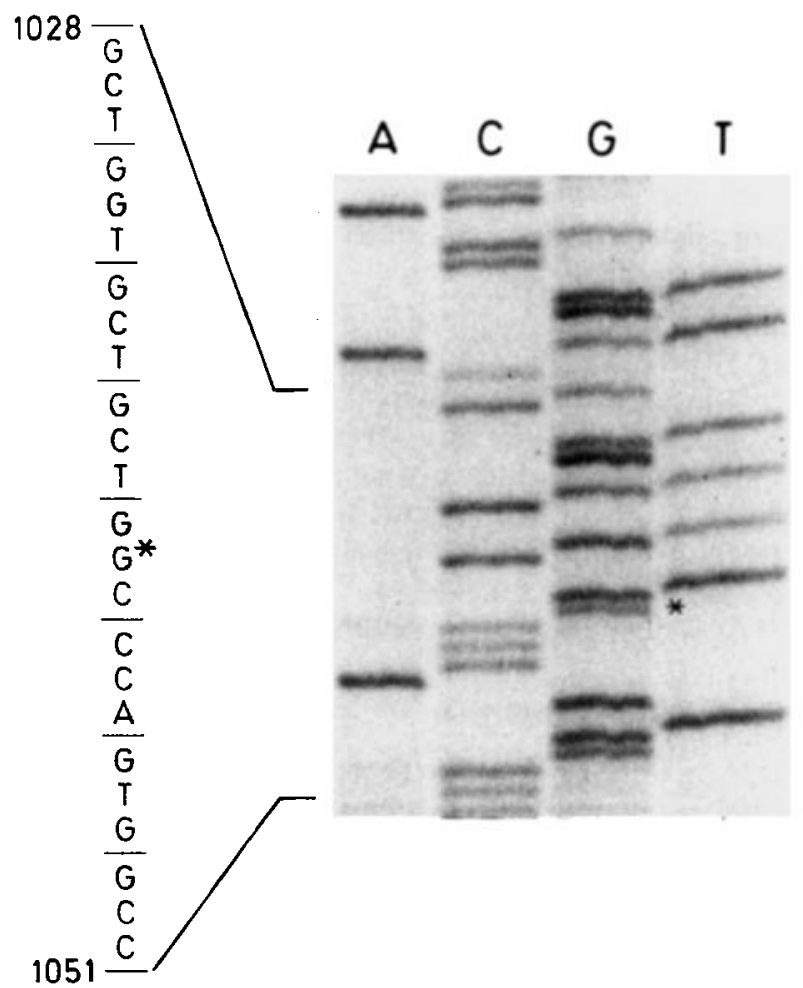

Fig. 2. Identification of an extra $G$ residue at position 1041 of the RF619 cDNA. The additional $\mathrm{G}$ nucleotide is marked by an asterisk. The specified sequence (left) reads positions 1028-1051 of the RF619 sequence, corresponding to Ala-Gly-Ala-Ala-Gly-Pro-Val-Ala (positions $333-340$ of the prefetuin sequence).



Fig. 3. Light-chain portions of rat fetuin, pp63, human $\alpha_{2}$-HS glycoprotein and bovine fetuin. (A) Comparison of the protein sequences predicted from clones RF619 and pp63, and the sequence of the rat fetuin light chain (RFI-1). The point of sequence divergence is marked by a solid triangle. Note that the C-terminal isoleucine residue was absent in the protein sequence of RFI-1, probably due to an exoproteolytic activity. (B) Comparison of the C-terminal sequences of various mammalian fetuins corresponding to the light chain of human $\alpha_{2}$-HS glycoprotein. ra, rat fetuin (this work); human $\alpha_{2}$-HS glycoprotein (Lee et al., 1987); bo, bovine fetuin (Dziegielewska et al., 1990). Conserved amino acid residues are boxed. Numbers identify the relative positions (prefetuin sequences) of the first given residue. except for the rat light-chain sequence which starts at position 1.

\section{Identification of the rat fetuin heavy and light chains}

The sequence of RFI-3.1 coincides with the predicted $\mathrm{N}$ terminus of rat fetuin (Fig. 1, residues 19-42); it is identical with the $\mathrm{N}$-terminal sequence of nine residues, recently established for a rat bone matrix protein (Mizuno et al., 1991). RFI-1 matches a sequence located at the extreme C-terminus of rat fetuin, but not to any other known protein sequence from the rat. The RFI-1 sequence starts at a position adjacent to the N-terminal residue of the light chain of human $\alpha_{2}$ HS glycoprotein (Fig. 1, residues $327-351$ ). Therefore, we 
conclude that RFI-1 represents the light chain and RFI-3.1 the corresponding heavy chain of rat fetuin, and that the two chains are interconnected by disulfide bridging.

Fragment RFI-1 of rat fetuin covers the C-terminal region diverging between the two predicted protein sequences of RF619 and pp63. The protein sequence of RFI-1 is in complete agreement with the amino acid sequence predicted from RF 619 , but not with the protein sequence deduced from clone pp63 (Fig. 3). Hence, the protein sequence data confirm the assignment of an extra $G$ residue at position 1041 of the RF619 cDNA sequence. Furthermore, this sequence fits well with the sequence alignments of the mammalian fetuin family, whereas the corresponding sequence derived from clone pp63 does not.

\section{Partial sequence analysis of the rat fetuin heavy chain}

To obtain further sequence data of the isolated protein, fragment RFI-3.1 was cleaved by endoproteinase Lys-C and the peptides were isolated by HPLC. Direct amino acid sequencing confirmed all the predictions based on the RF619 cDNA (Fig. 1), including the assignment of Glu at position 76 where Gln is predicted from the pp63 cDNA sequence. None of the sequenced fragments contained a (potential) $\mathrm{N}$ glycosylation site, however a single fragment spanning residues 249-268 contained a threonine at position 267 which probably carries an O-linked carbohydrate side chain as has been found for the corresponding positions of the human and bovine fetuins. Note that sequence polymorphism occurred at position 51 where either His or Asp were present in protein derived from individual animals.

In conclusion, our data strongly suggest that clones RF619 and pp63 encode one and the same protein, i.e. rat fetuin, and that the inconsistencies observed between the two cDNA are most probably due to cloning artifacts and/or sequencing errors of the pp63 cDNA.

\section{Homology of rat fetuin with other mammalian fetuins}

Comparison of the rat fetuin sequence derived from clone RF619 with the known sequences of other mammalian fetuins disclosed extensive sequence identities dissipated over the entire polypeptide chains including the C-terminal regions (not shown). The sequence identities range over $56.3-59.6 \%$ (protein level), and $72.5-74.9 \%$ (cDNA level). The typical tripartite structure of mammalian fetuins composed of two N-terminally located cystatin-like domains (D1, D2; Müller-Esterl et al., 1985; Elzanowski et al., 1988) and a single C-terminal domain (D3) unique to the fetuins (Kellermann et al., 1989; Rawlings et al., 1990) is also shared by rat fetuin. The Nterminal portion of D3 (residues $253-297$ ) which is characterized by the abundance of proline in other mammalian fetuins, is also present in the rat protein $(29 \%$ of the positions are occupied by Pro). Likewise, dibasic cleavage sites for proteolytic processing (Arg-Lys/Arg), acceptor sequences for $\mathrm{N}$ glycosylation (Asn-Xaa-Thr/Ser) and recognition sites for phosphorylation by casein-like kinases (Ser/Thr-Xaa-XaaAsp; Kemp and Pearson, 1990) are found in positions shared with the other mammalian fetuins (not shown).

\section{Functional properties of rat fetuin}

Identification of pp63 as authentic rat fetuin raises the question whether this protein is an inhibitor of the insulinreceptor-associated tyrosine kinase, and, if so, whether this

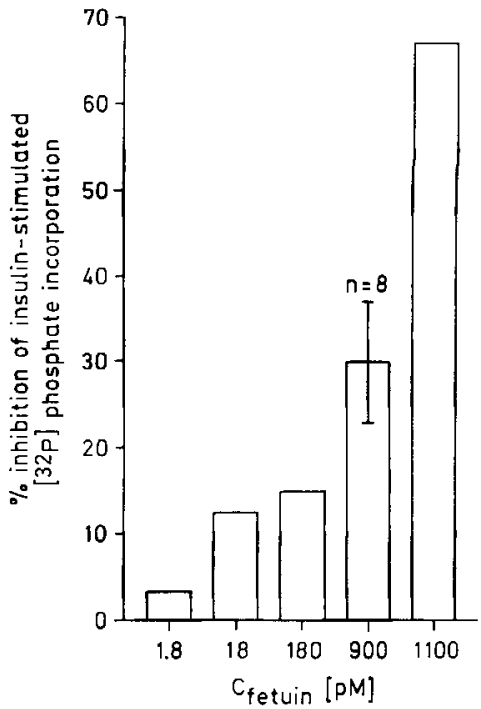

Fig. 4. Inhibition of insulin-stimulated substrate phosphorylation by rat fetuin. Solubilized insulin receptor from human placenta was treated with $1 \mu \mathrm{M}$ insulin in the presence of increasing concentrations of rat fetuin $(1.8-1100 \mathrm{pM})$ and subsequently tested for tyrosine kinase activity by determining the incorporation of $\left[{ }^{32} \mathrm{P}\right]$ phosphate into poly(Glu,Tyr). Bars indicate the percentage inhibition of substrate phosphorylation (no inhibition in the absence of fetuin).

functional role is unique to the rat protein or common to all mammalian fetuins. To address this issue, we tested the effect of purified rat fetuin on the tyrosine kinase activity associated with the human insulin receptor.

\section{Inhibition of substrate phosphorylation}

The insulin receptor was partially purified from human placenta, and its tyrosine kinase activity was measured by the incorporation of $\left[{ }^{32} \mathrm{P}\right]$ phosphate into the copolymer poly(Glu,Tyr) in the presence or absence of rat fetuin. Substrate phosphorylation induced by insulin $(1 \mu \mathrm{M})$ was inhibited by rat fetuin in a concentration-dependent manner and ranged from less than 5\% inhibition (1.8 pM fetuin present in the phosphorylation assay) to $67 \%$ inhibition, when the fetuin concentration was raised to $1.1 \mathrm{nM}$ (Fig. 4).

We also determined the inhibitory effect of other mammalian fetuins, i.e. human $\alpha_{2}$-HS glycoprotein and bovine fetuin, and of structurally related proteins, i.e. human histidine-rich glycoprotein and human L-kininogen (Rawlings and Barrett, 1990). All proteins were applied at a concentration of $50 \mu \mathrm{g} / \mathrm{ml}(0.74-1.1 \mathrm{nM})$. When insulin-induced substrate phosphorylation was attributed $100 \%$ on a relative scale, rat fetuin $(1.1 \mathrm{nM})$ reduced this value to $33 \pm 11 \%$, whereas the human and bovine homologues did not significantly inhibit the tyrosine kinase activity in three independent experiments $(106 \pm 18 \%$ and $99 \pm 19 \%$, respectively). The fetuin-related proteins L-kininogen and histidine-rich protein were also ineffective in kinase inhibition $(112 \pm 16 \%$ and $95 \pm 18 \%)$.

\section{Inhibition of insulin receptor autophosphorylation}

The autophosphorylation of the $95 \mathrm{kDa} \beta$ subunit of the insulin receptor was monitored in the presence $(0.67 \mathrm{nM})$ or absence of rat fetuin using $\left[\gamma^{32} \mathrm{P}\right] \mathrm{ATP}$ and recorded by autoradiography. The basic autophosphorylation activity of 


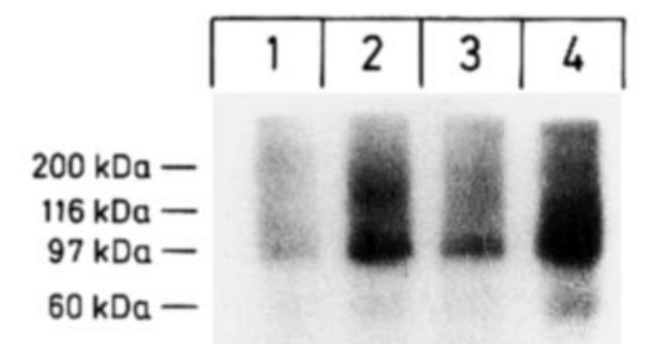

$45 \mathrm{kDa}-$

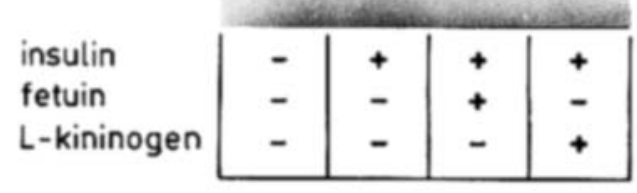

Fig. 5. Effect of rat fetuin on insulin-induced receptor autophosphorylation. Solubilized insulin receptor from human placenta was stimulated with $1 \mu \mathrm{M}$ insulin in the absence (lane 2) or presence of $0.67 \mathrm{nM}$ rat fetuin (lane 3) or $0.74 \mathrm{nM}$ human L-kininogen (lane 4 ), and incubated with $\left[\gamma_{-}{ }^{32} \mathrm{P}\right]$ ATP. To measure unstimulated autophosphorylation, the receptor was incubated in the absence of insulin and fetuin (lane 1). Phosphoproteins were separated by SDS/PAGE in a $7.5 \%$ polyacrylamide gel; the corresponding autoradiography is shown.

the solubilized human insulin receptor (Fig. 5, lane 1) was stimulated 2.8-fold $(100 \%)$ in the presence of $1 \mu \mathrm{M}$ insulin (Fig. 5, lane 2). Simultaneous incubation of the receptor with insulin and rat fetuin reduced the insulin-induced autophosphorylation by $33 \%$ (Fig. 5, lane 3; 1.9-fold stimulation). Incubation of the receptor with insulin and a fetuin-related protein, L-kininogen $(0.74 \mathrm{nM})$ gave a 4.1 -fold increase over the basic activity, signifying a stimulatory effect of this protein (Fig. 5, lane 4). Therefore, we conclude that rat fetuin is an in vitro inhibitor of the insulin-receptor-associated tyrosine kinase and this property is shared with the rat pp63 protein (Auberger et al., 1989).

We incubated the solubilized insulin receptor with 0.01 $n M^{125} \mathrm{I}$ - insulin and varying concentrations $(0.1-1000 \mathrm{nM})$ of the unlabeled hormone in the absence or presence of rat fetuin $(0.5 \mathrm{nM})$ to test the possibility that fetuin and insulin compete for the same binding site of the insulin receptor $\alpha$ subunit. A Scatchard plot analysis of the binding data revealed congruent displacement curves in the presence or absence of rat fetuin (not shown). We conclude that rat fetuin, like pp63 (Auberger et al., 1989), is a modulator of the receptor-associated tyrosine kinase activity operating at a region which is external to the ligand-binding site of the receptor.

\section{DISCUSSION}

Tyrosine kinase activity is associated with a large number of growth-hormone receptors, including the receptors for insulin, insulin-like growth factors, epidermal growth factors, platelet-derived growth factor and fibroblast growth factors. In addition, multiple oncogenes, e.g. $c$-src, $c$-neu, $c$-er $B$ and $c$ $k i t$, represent receptor-like molecules which express tyrosine kinase activity (for review, cf. Ullrich and Schlessinger, 1990). While substantial knowledge has accumulated on the structure and function of the receptor proteins, surprisingly little information is available regarding their natural modulators, e.g. inhibitors (Coughlin et al., 1987). The recently isolated and characterized phosphoprotein pp63 typifies such a kinase inhibitor (Auberger et al., 1989).

Molecular cloning and direct amino acid sequence analysis of rat fetuin now demonstrates that pp63 structurally belongs to the large family of mammalian fetuins (Dziegielewska et al., 1983; Jones et al., 1988). Furthermore, functional analysis of the isolated rat protein proves that fetuin is an efficient inhibitor of the tyrosine kinase activity associated with the insulin receptor. The fact that rat fetuin (this work) and pp63 (Auberger et al., 1989) were isolated by entirely different purification procedures suggests that the kinase inhibitor activity is a genuine property of rat fetuin rather than the characteristic of copurifying protein(s) which escaped identification by sequence analysis. Unlike rat fetuin, the homologues isolated from human and bovine plasma lack a significant inhibitor activity. This might be explained by the fact that only the phosphorylated form of $\mathrm{pp} 63$ /fetuin is active in tyrosine kinase inhibition, whereas the partially dephosphorylated form prevalent in the plasma is 10-fold less active (Le Cam et al., 1985; Auberger et al., 1989). Hence, the possibility remains that bovine and human fetuins were isolated from plasma in their dephosphorylated forms.

Fetuins are among the major plasma proteins with concentrations ranging over $0.4-5.0 \mathrm{~g} / \mathrm{l}$ (Dziegielewska et al., 1980). Quantification of fetuin in normal rat plasma by radioimmunoassay (Fink et al., unpublished results) revealed that the actual plasma concentration of the protein is at least two orders of magnitude higher than the previously published concentration of $2-3 \mathrm{mg} / \mathrm{l}$ (Auberger et al., 1989). A regulatory mechanism such as reversible protein phosphorylation (Cohen, 1982) would provide an efficient molecular switch to modulate fetuin's inhibitory activity.

The demonstration of the structural and functional identity of fetuin and pp63 has several major implications. First, the identification of one of the fetuins as a tyrosine kinase inhibitor might indicate that other members of this widely occurring protein family could serve the same function. Second, insulin-receptor-like molecules are known to play a crucial role during growth, development and differentiation. Intriguingly, the expression of the fetuins is most prominent during fetal development (Dziegielewska and Saunders, 1988), and fetuins have been localized in developing brain (Møllgård et al., 1984), embryonal cartilage (Lee et al., 1987) and ossifying tissue (Triffitt et al., 1976; Colclasure et al., 1988; Yang et al., 1991). The observed spatial and temporal distribution patterns of fetuins suggest an important role in the molecular control of growth and development which could be exerted through their inhibitor activity towards receptor kinases. The recent identification of a glycoprotein inhibiting the insulin receptor tyrosine kinase in a patient with non-insulin-dependent diabetes mellitus (Sbraccia et al., 1991) supports the conjecture that protein inhibitors might also play an important role in the regulation of tyrosine kinase activity in adult life. Finally, the detailed knowledge of structural properties of the fetuins will facilitate the elucidation of the molecular mechanisms underlying the inhibition of receptor-associated tyrosine kinases.

We are indebted to $M$. Arnhold for technical assistance, to $S$. Holz for secretarial help and to E. Haas for the preparation of the illustrations. This work was supported by grants-in-aid $\mathrm{Mu}$ 598/3-1 (to W.M.E.) from the Deutsche Forschungsgemeinschaft, $\mathrm{H}-5$ (to 
E.F.). Z-2 (to M.E.) and F-7 (to H.U.H.) from the Sonderforschungsbereich 207 of the University of Munich and the Fonds der Chemischen Industrie (to W.M.E.).

\section{REFERENCES}

Albrecht. G. J.. Hochstrasser, K. \& Schönberger, Ö. L. (1983) HoppeSeyler's Z. Physiol. Chem. 364, 1697-1702.

Auberger, P.. Falquerho, L.. Contreres, J. O., Pages, G., Le Cam, G. Rossi. B. \& Le Cam. A. (1989) Cell 58, 631-640.

Brown. W. M.. Christie, D. L., Dziegielewska, K. M. \& Saunders, N. R. (1991) Cell, in the press.

Cayatte. A. J.. Kumbla, L. \& Subbiah. M. T. R. (1990) J. Biol. Chem. 265. $5883-5888$.

Christie. D. L.. Dziegielewska, K. M., Hill, R. M. \& Saunders, N. R. (1987) FEBS Lett. 214, 45-49.

Cohen. P. (1982) Nature 296. 613-620.

Colclasure. G. C.. Lloyd. W. S., Lamkin, M., Gonnerman. W., Troxler, R. F.. Offner, G. D., Bürgi, W., Schmid, K. \& Nimberg, R. B. (1988) J. Clin. Endocrinol. Metab. 66, 187-192.

Coughlin, J. P., Donahoe, P. K.. Budzik, G. P. \& MacLaughlin, D. T. (1987) Mol. Cell. Endocrinol. 49, 75-85.

Daveau. M.. Davrinche. C., Djelassi. N.. Lemetayer, J., Julen, N., Hiron. M.. Arnaud. P. \& Lebreton. J. P. (1990) FEBS Lett. 273. $79-81$

Davis. L. G.. Dibner. M. D. \& Battey, J. F. (1986) Basic methods in molecula biology: Elsevier. New York.

Dziegielewska. K. M.. Evans, C. A. N., Fossan, G., Lorscheider, F. L.. Malinowska. D. H.. Møllgàrd. K., Reynolds, M. L., Saunders, N. R. \& Wilkinson. S. (1980) J. Phisiol. (Lond.; 300, $441-455$.

Dziegielewska, K. M.. Bock, E.. Cornelis, M. E. P., Møllgảrd, K., New. H. \& Saunders. N. R. (1983) Comp. Biochem. Physiol. 76 A, $241-245$,

Dziegielewska. K. M. \& Saunders, N. R. (1988) in Handbook of human growth and developmental biology (Meisami, E. \& Timiras, P. S., eds) pp. 169-191. CRC Press, Boca Raton.

Dziegielewska, K. M.. Brown. W. M.. Casey, S. J.. Christie, D. L., Foreman. R. C. Hill. R. M. \& Saunders, N. R. (1990) J. Biol. Chem. 265, 4354-4357.

Edge. A. S. B. \& Spiro. R. G. (1987) J. Biol. Chem. 262, $16135-$ 16141 .

Elzanowski. A.. Barker. W. C., Hunt. L. T. \& Seibel-Ross, E. (1988) FEBS Le'tt. 227. 167-170.

Falquerho. L.. Patey, G., Paquereau, L., Rossi, V., Lahuna, O., Szpirer. J.. Szpirer. C.. Levan. G. \& Le Cam. A. (1991) Gene (Amst, 98. 209-216.

Feinberg. A. P. \& Vogelstein. B. (1983) Anal Biochem. 132. 6-13.

Haasemann, M., Nawratil. P. \& Müller-Esterl, W. (1991) Biochem. J. $274.899-902$.
Hortin, G., Green, E. D., Baenziger. J. U. \& Strauss, A. W. (1986) Biochem. J. 235, 407-414.

Joncs, S. E., Driegielewska, K. M., Saunders, N. R., Christie, D. L., Sueiraz-Diaz, J. \& Szelke, M. (1988) FEBS Lett. 236. $411-414$.

Kellermann, J.. Haupt, H., Auerswald, E. A. \& Müller-Esterl. W. (1989) J. Biol. Chem. 264, 14121-14128.

Kemp. B. E. \& Pcarson, R. B. (1990) Trends Biochem. Sci. 15, $342-$ 344.

Kozak. M. (1989) J. Cell Biol. 108, 229-241.

Laemmli, U. K. (1970) Nature 227, 680-685.

Le Cam, A., Magnaldo, I., Le Cam, G. \& Auberger, P. (1985) J. Biol. Chem. 260, $15965-15971$.

Lee, C. C., Bowman, B. H. \& Yang, F. (1987) Proc. Natl Acad. Sci. USA 84. 4403-4407.

Lewis, J. G. \& André, C. M. (1980) Immunology 39, 317-322.

Mizuno, M., Farach-Carson, M. C., Pinero, G. J., Fujisawa, R., Brunn. J. C., Seyer, J. M., Bousfield, G. R., Mark. M. P. \& Butler, W. T. (1991) Bone Miner. 13, 1-21.

Møllgắrd, K., Reynolds, M. L., Jacobsen, M., Dziegielewska, K. M. \& Saunders, N. R. (1984) J. Neurocytol. 13, 497-502.

Müller-Esterl, W., Fritz, H., Kellermann, J., Lottspeich, F., Machleidt, W.\& Turk, V. (1985) FEBS Lett. 191, 221 - 226.

Pedersen, K. O. (1944) Nature 154, 575.

Puck. T. T., Waldren. C. A. \& Jones, C. (1968) Proc. Natl Acad. Sci. USA 59. 192-199.

Rawlings, N. D. \& Barrett, A. J. (1990) J. Mol. Evol. 30, 60-71.

Rohrlich, S. T. \& Rifkin, D. B. (1981) J. Cell. Physiol. 109, 1-15.

Sambrook, J., Fritsch, E. F. \& Maniatis, T. (1989) Molecular cloning, a laboratory manual, Cold Spring Harbor Laboratory. Cold Spring Harbor, New York.

Sanger. F., Nicklen, S. \& Coulson, A. R. (1977) Proc. Natl Acad. Sci. USA 74, 5463-5467.

Sbraccia, P., Goodman, P. A., Maddux, B. A., Wong, K. Y.. Chen, Y. D. I., Reaven. G. M. \& Goldfine, I. D. (1991) Diabetes 40. $295-299$.

Schmid. K. \& Bürgi. W. (1961) Biochim. Biophy's. Acta 47, 440-453.

Schultze, H. E., Heide, K. \& Haupt, H. (1962) Naturwissenschaften 49, 15.

Strauss, E. C., Kobori, J. A., Siu, G. \& Hood, L. (1986) Anal. Biochem. $154,353-360$.

Triffitt, J. T., Gebauer, U., Ashton, B. A., Owen, M. E. \& Reynolds, J. J. (1976) Nature 262, 226-227.

Ullrich, A. \& Schlessinger, J. (1990) Cell 61, 203-212.

Van Oss, C. J., Gillman, C. F., Bronson, P. M. \& Border, J. R. (1974) Immunol. Commun. 3, 329-335.

Von Heijne, G. (1986) Nucleic Acids Res. 14, 4683-4690.

Yang, F., Schwartz. Z., Swain, L. D., Lee, C. C. Bowman, B. H. \& Boyan, B. D. (1991) Bone (NY) 12, 7-15.

Yet, M. G., Chin, C. C. Q. \& Wold, F. (1988) J. Biol. Chem. 263. $11-117$.

Note added in the proof. Upon reexamination of their sequence data, Le $C a m$ et al. identified an additional $G$ residue in position 1083 of the pp 63 cDNA (corresponding to position 1041 of the RF 619 cDNA sequence). The corrected sequence is available at the EMBL sequence data bank under accession number M29758. 